\title{
Influence of Er,Cr:Ysgg Laser Associated or not To 5\% Fluoride Varnish in the Erosion Treatment of Bovine Enamel
}

\section{Influência do Laser Er,Cr:Ysgg Associado ou não ao Verniz Fluoretado 5\% no Tratamento da Erosão em Esmalte Bovino}

\author{
Leandro Silva Almeida ${ }^{\mathrm{a}}$; Gabriella Rodovalho Paiva ${ }^{\mathrm{b}}$; Vinícius Rangel Geraldo-Martins ${ }^{\mathrm{b}}$; Juliana Jendiroba Faraonic; \\ Regina Guenka Palma Dibbc; Cesar Penazzo Lepri*b
}

aUniversity of Uberaba, Dentistry Course. SP, Brazil.

${ }^{b}$ University of Uberaba, Stricto Sensu Graduate Program in Dentistry. SP, Brazil.

'University of São Paulo, Ribeirão Preto School of Dentistry, Department of Restorative Dentistry. SP, Brazil.

E-mail: cesar.lepri@uniube.br

Recebido em: 08/04/2019; Aprovado em: 24/09/2019

\begin{abstract}
The objective of this in vitro study was to evaluate the influence of the Er,Cr:YSGG laser associated or not to a desensitizing agent in the treatment of erosive lesions. Forty specimens with dimensions of $4 \mathrm{~mm} \times 4 \mathrm{~mm}$ and $3 \mathrm{~mm}$ thickness were divided into 4 groups (n $=10$ ): G1- no treatment; G2- 5\% fluoride varnish; G3- Er,Cr: YSGG; G4 - fluoride varnish + laser. The specimens were immersed in erosive drink 3 times a day for 1 minute with an average interval of 2 hours between cycles for a period of 10 days. The treatments were performed according to the groups and the surface roughness and the wear profile were analyzed by scanning confocal microscopy. The normality (Kolmogorov-Smirnov) and homogeneity (Levene's) of the tests were evaluated. After these analyzes, the surface roughness data were submitted to the statistical analysis of Variance Analysis (ANOVA). All tests adopted a significance level of 5\% $(\alpha=0.05)$. At the representative images of the wear profile, the morphology of bovine dental enamel in its control and eroded areas were compared and qualitatively discussed. As regard surface roughness, there was no statistically significant difference between the groups. The qualitative analysis of the loss of volume showed that all experimental groups showed significant superficial morphology differences. Considering the limitations of an in vitro study, it can be concluded that the treatments performed were not able to treat dental erosion satisfactorily, indicating the need for more treatment sessions.
\end{abstract}

Keywords: Tooth Erosion. Dental Enamel. Fluoride. YSGG Laser.

\section{Resumo}

O objetivo desse estudo in vitro foi avaliar a influência do laser Er,Cr:YSGG associado ou não a um agente dessensibilizante no tratamento de lesões erosivas. Foram confeccionados 40 espécimes com dimensões de $4 \mathrm{~mm}$ x $4 \mathrm{~mm}$ e $3 \mathrm{~mm}$ de espessura, divididos em 4 grupos ( $n=10$ ): G1- nenhum tratamento; G2-verniz fluoretado 5\%; G3-aplicação do laser Er,Cr:YSGG; G4-verniz fluoretado + laser. Os espécimes foram imersos em bebida erosiva, 3 vezes por dia, durante 1 minuto, com intervalo médio de 2 horas entre os ciclos, por um período de 10 dias. Os tratamentos foram realizados de acordo com os grupos e que foram analisados a rugosidade superficial e o perfil de desgaste por meio de microscopia confocal de varredura. Avaliou-se a normalidade (Kolmogorov-Smirnov) e homogeneidade (Levene's) dos dados. Após estas análises, os dados de rugosidade superficial foram submetidos ao teste estatístico de Análise de Variância (ANOVA). Todos os testes adotaram nivvel de significância de $5 \%(\alpha=0,05)$. Através da obtenção das imagens representativas do perfil desgaste, a morfologia do esmalte dental bovino em suas áreas controle e erodida foram comparadas e qualitativamente discutidas. Quanto à rugosidade superficial, não houve diferença estatisticamente significativa entre os grupos. A análise qualitativa da perda de volume mostrou que todos os grupos experimentais apresentaram diferenças significativas na morfologia superficial. Considerando as limitações de um estudo in vitro pode-se concluir que os tratamentos realizados não foram capazes de tratar a erosão dentária de forma satisfatória, indicando a necessidade de mais sessões de tratamento.

Palavras-chave: Erosão dentária. Esmalte dental. Flúor. Laser de YSGG.

\section{Introduction}

The dental erosion is classified as a non-carious lesion, which may be defined as a chemical-mechanical change responsible for causing loss of tooth structure without any bacterial involvement, leading the $\mathrm{pH}$ around the enamel below 5.5. Its prevalence affects the cervical, vestibular or palatine portion of dental elements, and may be multifactorial origin, in addition to the possibility of being a result of the aging of the teeth ${ }^{1.2}$.

The etiology of the eroded wear can be the result of extrinsic factors such as the ingestion of cola soft drinks, isotonic drinks, juices of citrus fruits ${ }^{3}$ and environment, as employees of chemical laboratories or intrinsic factors, where the change of $\mathrm{pH}$ is stimulated by hydrochloric acid present in the stomach that returns the oral cavity motivated by vomiting, regurgitation or reflux, as in cases of anorexia, bulimia and hiatal hernia ${ }^{2.4}$.

With loss of enamel, dentin can be affected by chemical, tactile, thermal agents and even osmotic stimuli, where there are reports of painful symptoms, then pain is caused, called dentin hypersensitivity. This pain can be described as throbbing, sharp, quick start, of short duration and ceased 
once the stimulus is removed ${ }^{1.5}$.

A anamnesis seeking to gather information of habits, systemic conditions and among other information is of extreme importance, to then subsequently remove this etiological factor for dealing with this type of injury with desensitizing substances in which can be tin chloride and potassium salts,

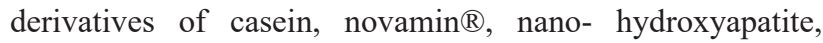
arginine, fluorine and laser².

Fluorine is important in the remineralization process, because it inhibits the demineralization, when there is presence of fluctuations in $\mathrm{pH}$, thus forming the fluorapatite ${ }^{7}$. It is known that fluoride can be found in various concentrations, either in the public water supply or in products for dental use, besides being considered a nutrient of paramount importance for the mineralized substances of the body, since their proper use brings benefits to both bone integrity and to tooth structure ${ }^{8.9}$.

In recent decades, the high power (surgical laser) has been used as a tool for prevention of dental caries and erosion by raising the resistance to acids aggressors to enamel. The Laser Er,Cr:YSGG has been used in the dental area in several procedures, such as in surgeries of soft and hard tissues and removal of caries.

In addition to the chemical characterization of erosion, the physical characteristics of the enamel surface should be evaluated to indicate the loss of tissue due to exposure with low $\mathrm{pH}$ values ${ }^{11}$. These factors have conventionally been evaluated by measurement of the parameters of surface roughness and loss of volume, carried out by means of optical microscopy, which does not promote damage to the surface of the specimen that is being assessed.

Thus, the objective of this study is to evaluate the influence of treatment with the Laser Er,Cr:YSGG associated or not to the fluoride varnish $5 \%$, analyzing the surface roughness and the profile of bovine enamel wear by means of confocal microscopy of laser scan .

\section{Material and Methods}

\subsection{Experimental design}

The sample of the experiment was 40 bovine enamel specimens divided in 4 groups $(\mathrm{n}=10)$. The factor under study was: treatment of specimens at four levels: G1- no treatment; G2- fluoride varnish 5\%; G3- application of laser Er,Cr:YSGG; G4- fluoride varnish+laser. The response variable was the quantitative analysis of surface roughness (parameter $\mathrm{Ra}$ in $\mu \mathrm{m}^{2}$ ) and qualitatively, the profile of wear $(\mu \mathrm{m})$.

\subsection{Selection of teeth}

20 bovine incisors were selected, without the presence of cracks and wear. The teeth were cleaned and then immersed in a solution of $10 \%$ formalin $(\mathrm{pH}=7)$ during 7 days for sterilization. Then, these teeth were washed and stored in distilled and deionized water at a temperature of $4^{\circ} \mathrm{C}$, changed daily for a period of 7 days.

\subsection{Preparation of specimens}

The incisors were sectioned separating the coronary portion of the root using a diamond disc under refrigeration in cutting machine ISOMET ${ }^{\circledR} 1000$ (Precision Saw Buehler, Illinois - USA). The first cutting was performed $1 \mathrm{~mm}$ above the enamel-cement junction. The second cut was performed in the mesio-distal direction, obtaining two halves (vestibular and lingual). Each half was sectioned again to obtain specimens in the initial dimensions of $4.25 \mathrm{~mm} \times 4.25 \mathrm{~mm}$. The specimens had their sides adjusted in the polishing, Arotec APL-4 (series 41042, Arotec S.A. Indústria e Comércio), using sandpaper $\# 600$, with the cooling water to the standardization in $4 \mathrm{~mm} x$ $4 \mathrm{~mm}$, resulting in a superficial area of $16 \mathrm{~mm} 2$. The polishing of external surface of the specimen was not performed. Variations in dimensions in $10 \%$, for more or less were admitted. Half the surface of each specimen was covered with insulating tape. Two layers of red nail cosmetic enamel and wax to sculpt were applied, performing their isolation. After this procedure, the isolating tape was removed, and each specimen was left with half of the free surface of protection made with enamel and wax. The specimens were stored in distilled and deionized water at a temperature of $4{ }^{\circ} \mathrm{C}$ until the completion of the proposed treatment, which were randomly divided into 4 groups $(\mathrm{n}=10)$, and each group received their treatment.

\subsection{Erosive Challenge}

The specimens were subjected to the erosive challenge in Sprite ${ }^{\circledR}$ (Uberlândia Refrescos LTDA, Uberlândia, MG, Brazil). Each group was placed separately in a becker during 1 minute on a magnetic stirrer (ABC-LAB, Model 221-1). After this time, the erosive solution was discarded, and the specimens were washed with distilled and deionized water for 10 seconds and were stored again in distilled water and placed in the oven at $37{ }^{\circ} \mathrm{C}$ between cycles. This procedure was performed 3 times a day with minimum intervals of 2 hours between the challenges, for a total period of 10 days. The specimens were stored at $4{ }^{\circ} \mathrm{C}$ immersed in distilled water until the moment of analysis. The enamel and the wax (control area) of each specimen were removed using the instrumental Lecron ${ }^{\circledR}$. There was no instrumental contact with the central surface of the specimen, only on the laterals.

\subsection{Treatment of the specimens}

The fluoride varnish (sodium fluoride 5\%) used was the Duraphat ${ }^{\circledR}$ (ColgatePalmolive Ind. e Com. Ltda, São Paulo, SP, Brazil) with disposable applicator (micro brush) and after 4 minutes the excess was removed with a sterile gauze. The laser equipment was Er,Cr:YSGG Waterlase (Millennium, Biolase Technologies Inc., San Clemente, USA), with the fiber containing $600 \mu \mathrm{m}$ in diameter (model of the tip: ZipTip MZ6 3mm). 


\subsection{Analysis of surface roughness and the profile of wear}

Prior to completion of the analysis, the specimens were immersed in a stainless steel ultrasonic and agitated for 5 minutes, and subsequently positioned parallel to the table of the confocal laser scan microscope (Olympus LEXT laser, Japan) with the aid of a paralelometer.

After selecting the central region of the specimen of $1 \mathrm{~mm} \times 1 \mathrm{~mm}$, the acquisition of images was performed with a magnifying lens 20x magnification. After obtaining the images, these were analyzed for the roughness parameter area (Ra) and profile of wear $(\mu \mathrm{m})$.

For the analysis of the surface roughness the central region encompassing the health area (reference) and the eroded area was measured. The data in $\mu \mathrm{m}^{2}$, were acquired by means of a specific software (OLS4000®).

The profile of wear was determined by the difference between the volume of the reference area and the eroded area between the middle line of the graph. The images representing the profile of wear were obtained in $3 \mathrm{D}$, and the morphological comparison of dental enamel was performed between the control area and the eroded area.

\subsection{Statistical analysis}

The data of surface roughness were subjected to tests of homogeneity (Levene's test) and normality (Kolmogorov Smirnov test). Being met these conditions, the test of Analysis of Variance (ANOVA) was performed. All tests adopted a significance level of $5 \%(\alpha=0.05)$.

At the representative images of the wear profile, the morphology of bovine dental enamel in its control and eroded areas were compared and qualitatively discussed.

\section{Results and Discussion}

\subsection{Surface roughness}

There was no statistically significant difference in the superficial roughness among the groups $(\mathrm{p}>0.05)$, indicating that a single treatment session was not able to reduce the roughness of the eroded dental enamel .

The mean values of surface roughness followed by the standard deviation for each group are described in Table 1.

Table 1 - Mean values (standard deviation) of surface roughness of area $\left(\mu \mathrm{m}^{2}\right)$ of the studied groups, considering the reference area (control region) and the eroded area followed by treatment

\begin{tabular}{|cc|c|}
\hline Groups & Control Region & $\begin{array}{c}\text { Eroded region } \\
\text { followed by } \\
\text { treatment* }\end{array}$ \\
G1 - no treatment & $0.945(0.132)$ & $3.587(0.431)^{\text {a }}$ \\
\hline G2 - varnish fluoride 5\% & $0.907(0.119)$ & $3.206(0.511)^{\text {a }}$ \\
\hline G3 - Laser Er,Cr:YSGG & $0.938(0.129)$ & $3.457(0.406)^{\text {a }}$ \\
\hline G4 - varnish+laser & $0.925(0.130)$ & $3.366(0.548)^{\text {a }}$ \\
\hline
\end{tabular}

*Lowercase equal letters represent statistical similarity $(\mathrm{p}>0.05)$.

Source: Research data.

\subsection{Profile of wear}

The qualitative analysis (Figure 1) revealed significant differences in the surface morphology, especially when the control region was compared to the eroded region followed by treatment, regardless of the treatment group.

Figure 1 - Image representative of profilometry 3D. Control Region to the left and eroded region followed by the treatment to the right (highlighted in yellow).

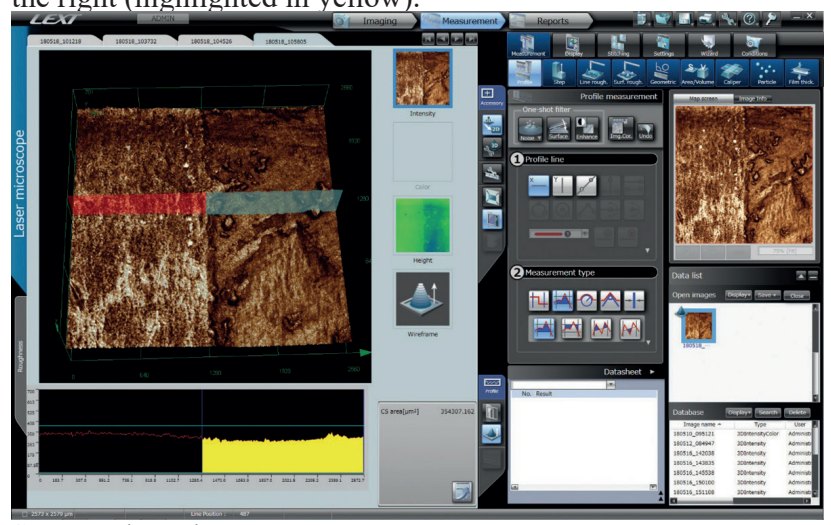

Source: The authors.

The erosion pattern shown in yellow occurred in all the experimental groups, representing that the erosion caused loss of volume that could not be handled after a single session of treatment.

In this study, the specimens were divided into control and experimental area, therefore, during the erosive challenge with the erosive drink only the experimental area was eroded, i.e., all specimens obtained an area not treated and not eroded.

Bovine teeth were used, due to the ease of obtaining and standardization of results, becoming models of studies, in addition to possessing composition and characteristics similar to that of human teeth ${ }^{12.13}$.

For the study, it was opted for the use of soda Sprite ${ }$, as well as Coca-Cola ${ }^{\circledR}$, has low $\mathrm{pH}$ around $2.5^{14.15}$ and high erosive potential, i.e., it is able to interfere in the DES/RE process. The erosion cycles were performed during three times a day, with a minimum interval of two hours between them, during a period of 10 days.

The dental erosion consists of the progressive and irreversible loss of tooth structure, either enamel or dentin resulting from the action of acids, without the bacterial involvement ${ }^{16}$.

After the analysis of surface roughness, it was observed that the treatments, with only a single application, were not capable of reducing the surface roughness of bovine enamel, when there is a comparison of control and experimental areas.

For the descriptive analysis of the profile of wear, it became evident that erosion was responsible for the loss of volume of all the analyzed groups.

Due to the limitation of the enamel in not possessing biological capacity of spontaneous form when $\operatorname{lost}^{3}$, i.e., the enamel manages to remineralize, but never recovers in 
volume.

Therefore, the treatments carried out were not able to deal with the dental erosion in a satisfactory way, therefore, the null hypothesis of the study was not rejected.

Regarding the treatments, studies have shown that the topical application of fluoride can

protect the tooth structure against erosion agents ${ }^{16-18}$. And this is assigned, due to the deposition of material similar to calcium fluoride on the tooth surface, protecting the dental tissues against the demineralization, temporarily ${ }^{20}$. The loss of enamel can lead to dentin exposure and future clinical signals of dentin hypersensitivity.

The fluoride compounds are the most commonly used for the reduction of dentin hypersensitivity ${ }^{21,22}$. Consequently, the application of fluoride with high concentration was used in the present study, as the varnish fluoride Duraphat t Colgate Palmolive Company (New York, USA), with the purpose of treating erosive lesions.

The primary preventive measure for dental erosion is to reduce the frequency and duration of exposure to acid. As it is difficult to control the patient's behavior, such as the frequency of intake of acid or particular habits of consumption, other strategies have been proposed for controlling dental erosion which are much less dependent on the fulfilment of the patient. The most tested alternative is to increase the acid resistance of the teeth through the application of fluoride ${ }^{6}$.

However, the effectiveness of the treatments with fluoride is very limited, especially when the tooth structure is often subjected to acidic conditions, and this requires a higher frequency of use of fluoride products ${ }^{23}$. The application of varnish fluoride, carried out by the professional, can demonstrate superior results than the treatments for domestic use $^{24}$.

The reduction of the dentin permeability occurs due to the obliteration of the dentin seminiferous, however this result was temporary, as the crystals were partially dissolved in the saliva $^{27}$.

Gaffar $^{5}$ in his study with the varnish fluoride Duraphat observed the formation of crystals of calcium fluoride which prevented the opening of dentin tubules, promoting remineralization and consequently a lasting relief of dentin hypersensitivity. The potassium oxalate is a desensitizing agent that acts in the obliteration of the tubules and depolarization of nerve endings; it is presented both in the form of toothpaste and topical applications ${ }^{26}$.

The increase in the viscosity of the solutions of fluoride agents reduces the loss of tooth enamel caused by erosion and the results of the treatment may be directly related to the type of fluoride agent used, either in the form of oral solution to mouth washing gel or varnish and its frequency of application ${ }^{28}$.

Other studies ${ }^{29,30}$ showed that the use of desensitizing agents produces a response of short duration, i.e., the effect of the treatment is not durable, therefore the application of the varnish fluoride was proposed together in association with the Laser Er,Cr:YSGG.

The combination of fluoride and laser irradiation has been reported in the literature ${ }^{31.32}$. These studies showed that this association decreases relatively the enamel demineralization, more than any fluoride treatment or laser irradiation alone and as results, obtained that the association of laser irradiation with varnish fluoride was more effective, this is due to the fact that the incorporation of ions on the surface of the specimen was enhanced when they used the laser on the varnish, leaving the surface more resistant to acids.

The application of Laser Er,Cr:YSGG on tooth surface causes an increase in temperature and alters its chemical structure, leaving the surface less soluble ${ }^{32}$. Thus, studies have shown that the therapy using the laser showed an effective reduction of dentin hypersensitivity in comparison with conventional desensitizing systems ${ }^{33.34}$.

There is a great variety in the methods for use of fluoride agents, and lasers that have extensive interaction with the dental tissues, due to their high absorption coefficient in both water and in the hydroxyapatite.

Therefore, it is important to study the appropriate parameters for the use of these materials in association, which can promote effective and long-lasting results, avoiding future exposure of dentin. Therefore, in cases of dental erosion installed, it is also important to develop methods of treatment and control of dentin hypersensitivity, generating greater comfort to the patient, which can meet a large portion of the population.

In this study, the use of confocal laser scanning enabled the morphological evaluation of the tooth surface, in which was observed - the surface and the loss of specific structures that characterize the dental enamel ${ }^{3}$.

Other analyzes can be performed to check if there is interference in othersmechanical properties of enamel, either in the bond strength or in the microhardness.

The treatments performed in association with the Laser Er,Cr: YSGG were not able to deal with the dental erosion satisfactorily, with only one application, therefore, further studies are needed in order to measure the loss of volume. Furthermore, it is also important the achievement of the treatments in different periods.

\section{Conclusion}

Considering the results obtained and the limitations of an in vitro study, concluded that there was no statistically significant difference in the superficial roughness among the groups in relation to the negative control group. For the profile of wear, all groups presented alterations in morphology, indicating the need for further treatment sessions.

\section{Acknowledgments}

To Fundação de Amparo à Pesquisa de Minas Gerais (FAPEMIG) for scientific initiation scholarship (PIBIC - 
FAPEMIG 2017/6) and the Program of Support to the research of the University of Uberaba (PAPE - UNIUBE) for the development of the research. The present study was carried out with support from Coordenação de Aperfeiçoamento de Pessoal de Nível Superior (CAPES) - Funding code 001.

\section{References}

1. West NX, Lussi A, Seong J, Hellwig E. Dentin hypersensitivity: pain mechanisms and aetiology of exposed cervical dentin. Clin Oral Invest 2012;17:S1-S19. 10.1007/s00784-012-0887-x.

2. Dias, ARC et al. Tratamento de lesões cervicais. In: Pereira JC, Anauate-Netto, c, Gonçalves Aa. Dentística: Uma abordagem multidisciplinar. São Paulo: Artes Médicas; 2014.

3.Colombo M, Mirando M, Rattalino D, Beltrami R, Chiesa M, Poggio C. Remineralizing effect of a zinc-hydroxyapatite toothpaste on enamel erosion caused by soft drinks: Ultrastructural analysis. J ClinExp Dent 2017;9:e861-868 doi $10.4317 /$ jced.53790.

4. Ostrowska A, Szymanski W, Kolodziejczyk L, Rzepkowska EB.Evaluation of the Erosive Potential of Selected Isotonic Drinks: In Vitro Studies. Adv Clin Exp Med 2016; 25:1313-1319 doi $<$ http://dx.doi.org/10.17219/acem/ 62323.

5. Farag ZHA, Awooda EM. Dental erosion and dentin hypersensitivity among adult asthmatics and non-asthmatics hospital-based: a preliminary study. Open Dent J 2016;10:58793 doi 10.2174/1874210601610010587.

6. Comar LP, Cardoso CA, Charone S, Grizzo LT, Buzalaf MA, Magalhães AC. TiF4 and NaF varnishes as anti-erosive agents on enamel and dentin erosion progression in vitro. J Appl Oral Sci 2015; 23:14-8 doi dx.doi.org/10.1590/1678-775720140124.

7. Lammers PC, Borggreven JM, Driessens FC. Influence of fluoride and $\mathrm{pH}$ on in vitro remineralization of bovine enamel. Caries Res 1992;26(1):8-13 doi 10.1159/000261418.

8. Buzalaf MAR, Kobayashi CAN, Tucunduva, S. Histórico do uso de fluoretos em saúde bucal. In: Buzalaf, MAR. Fluoretos e saúde bucal. São Paulo: Livraria Santos; 2008.

9. Alves RX, Fernandes GF, Razzolini MTP, Frazão P, Marques RAA, Narval PC. Evolução do acesso à água fluoretada no Estado de São Paulo, Brasil: dos anos 1950 à primeira década do século XXI. Cad. Saúde Pública 2012 doi dx.doi.org/10.1590/S0102311X2012001300008.

10. Oliveira RM, Souza VM, Esteves CM, de Oliveira Lima-Arsati YB, Cassoni A, Rodrigues JA, Brugnera Junior A. Er,Cr:YSGG Laser Energy delivery: pulse and power effects on enamel surface and erosive resistance. Photomed Laser Surg 2017;35(11):639646. doi: 10.1089/pho.2017.4347.

11. Fujii M, Kitasako Y, Sadr A, Tagami J. Roughness and $\mathrm{pH}$ changes of enamel surface induced by soft drinks in vitro applications of stylus profilometry, focus variation 3D scanning microscopy and micro pH sensor. Dent Mater J 2011;30:404-410 doi http://dx.doi.org/10.4012/dmj.2010-204.

12. Tanaka JLO, Medici Filho E, Salgado JA,Salgado MAC, Moraes LC,Moraes MEL et al. Comparative analysis of human and bovine teeth: radiographic density. Braz Oral Res 2008;22(4):346-51 doi: 10.1590/S1806-83242008000400011.

13. Wegehaupt F, Gries D, Wiegand A, Attin T.Is bovine dentine an appropriate substitute for human dentine in erosion/abrasion tests?. J Oral Rehabil 2008;35:390-39 doi: 10.1111/j.13652842.2007.01843. $\mathrm{x}$.

14. Lussi A, Megert B, Shellis RP, Wang X. Analysis of the erosive effect of different dietary substances andmedications. Bras J Nutr 2012;107(2):252-262 doi: 10.1017/S0007114511002820, 2012.

15. Alexandria AK, Vieira TI, Pithon MM, da Silva Fidalgo TK, Fonseca-Gonçalves A, Valença AM, et al. In vitro enamel erosion and abrasion-inhibiting effect of different fluoride varnishes. Arch Oral Biol 2017;77:39-43. doi: 10.1016/j.archoralbio.2017.01.010.

16. Moynihan PJ. The role of diet and nutrition in the etiology and prevention of oral diseases. Bulletin of the World Health Organization. 2005;83:694-9.

17. Wiegand A, Magalhães AC, Attin T: Is titanium tetrafluoride (TiF4) effective to prevent carious and erosive lesions? A review of the literature. Oral Health Prev Dent 2010;8:159-64 doi http:// dx.doi.org/10.1016/j.

18. Scaramucci T, Borges AB, Lippert F, Frank NE, Hara AT: Sodium fluoride effect on erosion-abrasion under hyposalivatory simulating conditions. Arch Oral Biol 2013;58:1457-63 doi http://dx.doi.org/10.1016/j. Archoralbio.2013.06.004.

19. Scaramucci T, Borges AB, Lippert F, Zero DT, Aoki IV, Hara AT: Anti-erosive properties of solutions containing fluoride and different film-forming agents. J Dent 2015;43:458-65 doi doi. org/10.1159/000443619.

20. Magalhães AC, Wiegand A, Rios D, Buzalaf MA, Lussi A. Fluoride in dental erosion. Monogr Oral Sci 2011;22:158-70 doi doi.org/10.1159/000325167.

21. Van den berghe, L,De boever, J,Adriaens, PA. Hyperesthésie du collet: ontogenèse etthérapie. Un status questionis. Rev Belge Med Dent 1984;39(1):2-6.

22. Camilotti V, Zilly J, Busato Pdo M, Nassar CA, Nassar PO. Desensitizing treatments for dentin hypersensitivity: a randomized, split-mouth clinical trial. Braz Oral Res 2012;26:2638 doi dx.doi.org/10.1590/S1806-83242012000300013.

23. Huysmans MC, Young A, Ganss C. The role of fluoride in erosion therapy. In: Lussi A, Ganss C. Erosive Tooth wear: from diagnosis to therapy. Monogr Oral Sci. Basel 2014;25:230-43 doi dx.doi.org/10.1159/000360555.

24.Sar Sancakli H, Austin RS, Al-Saqabi F, Moazzez R, Bartlett $D$. The influence of varnish and high fluoride on erosion and abrasion in a laboratory investigation. Aust Dent J 2015;60(1):3842 doi: 10.1111/adj.12271.

25. Gaffar A. Treating hypersensitivity with fluoride varnishes. Compend Contin Educ Dent 1998; 19:1088-90.

26. Assis JS, Rodrigues LK, Fonteles CS, Colares RC, Souza AM,Santiago SL. Dentin hypersensitivity after treatment with desensitizing agents: a randomized, double-blind, split-mouth clinical trial. Braz Dent J 2011;22:157-16 doi /dx.doi.org/10.1590/ S0103-64402011000200012.

27. Stead WJ, Orchardson R; Warren B. A mathematical model of potassium ion diffusion in dentinal tubules. Arch Oral Biol 1996;41(7): 679-87 doi.org/10.1016/S0003-9969(96)00073-8.

28. Sakae LO, Bezerra SJC, João-Souza SH, Borges AB, Aoki IV.An in vitro study on the influence of viscosity and frequency of application of fluoride/tin solutions on the progression of erosion of bovine enamel.Arch Oral Biol 2018;89:26-30 doi 10.1016/j. archoralbio.2018.01.017.

29. Aranha AC, Pimenta LA,Marchi GM. Clinical evaluation of de- sensitizing treatments for cervical dentin hypersensitivity. Braz Oral Res 2009;23(3):333-9 /dx.doi.org/10.1590/S180683242009000300018 .

30. Dos Reis Derceli, J et al. Effect of pretreatment with an Er:YAG laser and fluoride on the prevention of dental enamel 
erosion. Lasers Med Sci 2015;30(2):857-62. doi: 10.1007/ s10103-013-1463-6.

31. Moslemi M, FekrazaD R, Tadayon N, Ghorbani M, Torabzadeh H, Shadkar MM. Effects of ER,Cr:YSGG laser irradiation and fluoride treatment on acid resistance of the enamel.Pediatr Dent 2009.31(5):409-13.

32. Freitas PM, Raposo - HiloM, Eduardo CP, Featherstone JD. In vitro evaluation of erbium,chromium:yttrium-scandium-galliumgarnet laser-treated enamel demineralization. Lasers Med Sci
2010;25(2):165-70. doi: 10.1007/s10103-008-05974.

33. Schwarz F.Desensitizing effects of an Er:YAG laser on hypersensitive dentine. A controlled, prospective clinical study. J Clin Periodontol 2002;29 (3):211-5.211- 5.

34. Ehlers V, Ernst CP, Reich M, Kämmerer P, Willershausen B. Clinical comparison of gluma and Er:YAG laser treatment of cervically exposed hypersensitive dentin. Am J Dent 2012;25(3):131-5 